внесок філософської, художньої, міфологічної, релігійної та практичної (яка формується в процесі життєдіяльності й потребує об'єктивування) [5].

6. Принцип врахування вікових та індивідуальних можливостей абстрагувальної, систематизуючої та іншої інтелектуальної діяльності учнів.

Під час структурування змісту навчання географії важливо зважати, що для формування адекватного образу світу у школярів доцільно використати підхід, у якому кількість складників образу світу співвідноситься з рівнями організації матерії [5]: а) матеріальна організація світу; б) жива природа; в) людське суспільство; г) людина як частина світу. Перший рівень передбачає поступове введення інформації про будову від мікро- до мегаскопічних явищ i процесів; другий - вивчення біоценотичних, популяційно-видових, організменних процесів; третій - процес взаємодії людини з суспільством, собою; четвертий - широкий діапазон психологічних, інтелектуальних, емоційно-вольових та інших процесів, їхня цілісність, взаємозв'язок між собою і глибинний взаємозв'язок біохімічних, енергетичних, психічних, інтелектуальних, ментальних процесів з навколишнім світом.

В оновленому змісті навчання блоки знань про предмети, явища природи, закономірності й закони іiі існування мають формуватись спеціально так, щоб зміст навчання ускладнюється поступово. У результаті формуються когнітивні структури, у яких фіксується частина активізованого інтелектуального досвіду учня i досить значна частина інформації, передбаченої програмою навчання з географії, яка містить засвоєні блоки спеціальних знань про предмети, явища природи, суспільства, закономірності й закони.

\title{
Література
}

1. Амосов Н. М. Энциклопедия Амосова. Алгоритм здоровья. Человек и общество / Н.М. Амосов. - М.: Сталкер, 2003. - 464 с. 2. Эйнштейн А. Собрание научных трудов : в 4-х т. / А. Эйнштейн; под ред. И. Е. Тамма, Я. О. Смородинского, В. Г. Кузнецова. - Т. 4. - Статьи, рецензии, письма. - М. : Наука, 1967. - 680 с. 3. Кодлюк Я. П. Шкільний підручник як організатор засвоєння навчального матеріалу / Я. П. Кодлюк // Проблеми сучасного підручника: [зб. наук. праць]. - К. : Пед. думка, 2003. - Вип. 4. - С. 10-16. 4. Назаренко Т. Г. Теоретичні і методичні аспекти сучасного підручника з курсу «Загальна географія» / Т. Г. Назаренко // Проблеми сучасного підручника: зб. наук, праць. - К.: Пед. думка, 2003. - Вип. 4. - С. 227-229. 5. Носенко Е. Я. «Картина світу» як інтегруючий та гуманізуючий фактор у змісті освіти / Е. Я. Носенко. - Дніпропетровськ: Вид-во Дніпропетров. ун-ту, 1996. - 74 с. 6. Пиаже Ж. Избранные психологические труды / Жан Пиаже. М. : Междунар. пед. академия, 1994. - 680 с. 7. Топузов О. М. Новий підручник з економічної і соціальної географії світу / О. М. Топузов // Географія та основи економіки в школі. - 2003. - № 4. С. 20. 8. Цехмистро И. 3. Холистическая философия науки / И. 3. Цехмистро. - Сумы: Университет. книга, 2002. - 363 с. 9. Schroder Н. М. Levels of information processing / H. M. Schroder, M. J. Driver, S. Streufert // Thought and Personality / Warr P.b/ ( ed.). - Baltimor Penguin Books Inc., 1970. - P. 174-191.

УДК 371.06

Людмила Лисогор

\section{ВИКОРИСТАННЯ ЕЛЕКТРОННИХ НАВЧАЛЬНИХ ПОСІБНИКІВ НА УРОКАХ ПРИРОДОЗНАВСТВА В ПОЧАТКОВІЙ ШКОЛІ}

Лисогор Л. П. Використання електронних навчальних посібників на уроках природознавства в початковій школі.

У статті аналізуються визначення поняття «електронний навчальний посібник». Розглядаються методичні, дидактичні аспекти використання електронних навчальних посібників у навчальному процесі початкової школи, розкриваються переваги електронного засобу порівняно з традиційним друкованим підручником.

Ключові слова: електронний навчальний посібник, індивідуалізація, компетентнісний підхід.

Лисогор Л. П. Использование электронных учебных пособий на уроках природоведения в начальной школе.

В статье анализируются определения понятия «электронное учебное пособие». Рассматриваются методические, дидактичные аспекты использования электронных учебных пособий в учебном процессе начальной школы, раскрываются преимущества электронного средства в сравнении с традиционным печатным учебником.

Ключевые слова: электронное учебное пособие, индивидуализация, компетентностный подход. 
Lysogor L. P. Use of e-books of initial school on the lessons of natural history.

The article analyzes the definition of the concept «electronic text-book». The paper considers methodological, didactic aspects of the use of electronic textbooks in the learning process of elementary school. The author substantiates benefits of electronic device over the traditional printed textbook.

Key words: e-book, individualization, a competence-based approach.

На сучасному етапі розвитку людства навчальний процес неможливо уявити без використання сучасних засобів навчання. Особливе місце серед них посідають електронні навчальні ресурси, у тому числі електронні навчальні посібники (ЕНП).

Мета статті полягає в обгрунтуванні поняття «електронний посібник» та визначенні педагогічних умов його використання в навчальному процесі початкової школи.

Електронні навчальні посібники відносяться до аудивізованих засобів навчання і можуть частково або повністю заміняти чи доповнювати чинні друковані підручники. ЕНП можуть бути тим засобом навчання, під час застосування якого діяльність учителя й учня перебувають у тісному взаємозв'язку.

Термін «електронний посібник» останнім часом широко використовується у педагогічній науці. При цьому нині не подано чіткого визначення сутності ЕНП:

- програмно-методичний навчальний комплекс, який відповідає чинній навчальній програмі і забезпечує можливість учню самостійно або за допомогою вчителя засвоїти навчальний предмет чи його розділ [1];

- електронне навчальне видання (ЕНВ), яке містить сукупність графічної, текстової, цифрової, музичної, відео-, фото та іншої інформації, а також друковану документацію користувача [9];

- електронне навчальне видання, яке містить матеріал із певної науково-практичної галузі знань, що забезпечує творче й активне засвоєння знань учнями [8];

- навчальне видання, яке містить системно викладений матеріал навчальної дисципліни або iii розділу та відповідає вимогам державного стандарту і чинній навчальній програмі [5];

- текст, представлений в електронній формі, забезпечений широкою системою взаємозв'язків, які дозволяють миттєво переходити від одного фрагмента до іншого [7];

- електронний навчальний посібник - це комплекс інформаційних, методичних і програмних засобів, спрямований на вивчення окремої навчальної дисципліни, що містить питання та завдання для самоконтролю й перевірки знать, а також забезпечує зворотній зв'язок [4].

Багатогранність визначень окресленого поняття засвідчує те, що зацікавленість до використання електронних навчальних посібників в освітньому процесі останнім часом зростає.

В аспекті нашого дослідження ми можемо подати таке визначення поняття «електронний посібник»: це навчальний комплекс, який відповідає чинному державному навчальному стандарту, створений з урахуванням компетентнісного підходу, що забезпечує індивідуалізацію навчальної діяльності учнів.

Перед тим як розпочати використання ЕНП у навчальному процесі, необхідно визначити, 3 якою метою засоби інформатизації будуть використані в освітньому процес- оптимізація навчального процесу або упровадження особистісно зорієнтованого підходу. Залежно від цього визначаються загальні та часткові методичні завдання, які можна досить успішно розв'язувати за допомогою електронних посібників.

Першій, вищевказаній меті відповідають такі завдання:

- розширення спектру джерел навчальної інформації;

- розвиток пізнавальних інтересів молодших школярів;

- збільшення обсягу сприйняття навчальної інформації.

Демонстрація яскравих слайдів, відеофрагментів або анімацій $є$ дійсно ефективним прийомом. Найбільш розповсюдженою формою організації діяльності молодших школярів у цьому випадку $є$ фронтальна робота 3 класом, а для вчителя - проблемна бесіда. 3-поміж проблем, пов'язаних з таким підходом, назвемо надмірне використання наочності і як наслідок уповільнення процесу інтеріоризації, зниження уваги до навчального матеріалу у дітей із переважно кінестетичним типом сприйняття інформації. Профілактика - використання та дотримання рекомендованого оптимального часового режиму і надання бесіді, яка проводиться 3 демонстрацією електронної наочності, розвивального характеру, тобто надання їй проблемності. 
Якщо електронні посібники планується використовувати під час уроку відповідно до особистісно зорієнтованого підходу до навчання, можна сформулювати такі завдання:

- урізноманітнення видів навчальної діяльності;

- розвиток загальнонавчальних умінь і навичок;

- індивідуалізація процесу навчання.

Відповідно до вищезазначених завдань форми організації навчальної діяльності молодших школярів урізноманітнюються - це фронтальна і групова робота, індивідуальне виконання навчальних завдань, робота в парах. 3-поміж можливих прийомів необхідно виокремити ті, які спрямовані на активізацію пізнавальної діяльності:

- індивідуальна робота з електронним навчальним матеріалом, спрямована на розвиток дослідницьких навиків та самоконтролю;

- робота в парах для одержання консультативної допомоги, розвитку навичок спільної навчальної діяльності, взаємодопомоги, відповідальності за загальний результат;

- використання електронних ресурсів як джерела навчальної інформації;

- використання сучасних інформаційних технологій для оформлення результатів індивідуальної або групової проектної діяльності;

- виконання інтерактивних завдань, які стимулюють пізнавальну діяльність;

- розвиток слухового і візуального сприйняття інформації, організаційних навикчок;

- дублювання колективно-індивідуальної роботи й індивідуального виконання інтерактивних завдань задля створення еталону для самоперевірки, підготовки матеріалу для колективного обговорення тощо.

Електронні посібники надають змогу розв'язувати вчителю такі методичні завдання:

- детальне ознайомлення молодших школярів із навчальним предметом;

- контроль та оцінювання навчальних досягнень молодших школярів;

- розвиток навчально-предметних умінь [4].

На прикладі розглянемо можливості використання ЕНП на уроках природознавства в початковій школі.

Спрямованість на розвиток логічного й образного мислення за допомогою використання яскравої, виразної наочності на уроках природознавства знайшла своє відображення у створенні специфічного ілюстративно-довідкового матеріалу, який розміщений у розділі «Навчайтеся» кожної теми. Наприклад, під час вивчення теми «Повітря навколо нас. Властивості повітря» учні, ознайомлюючись 3 властивостями повітря, визначають, за допомогою яких дослідів можна довести, що під час нагрівання повітря розширюється, а під час охолодження - стискається. У цьому випадку вдалим буде використання flashpoликів. Поєднання звукового супроводу, анімації, короткого пояснення та символьно-знакових записів надає змогу використовувати ці матеріали для фронтальної й індивідуальної роботи.

Як тренувальні вправи в електронних навчальних посібниках використовуються завдання, спрямовані на засвоєння певних природничих понять, як правило, вони створюються у вигляді гри, у якій учню необхідно обрати правильну відповідь.

Важливого значення, на наш погляд, набувають ЕНП під час вивчення розділу «Рослини». Витрачаючи менше часу на зображення різних груп рослин, можна приділяти більше уваги відпрацюванню практичних умінь - умінню класифікувати рослини за різними ознаками, активно використовуючи зорову, асоціативну та емоційну пам'ять молодших школярів. В окремих завданнях нами здійснюється аналіз результатів виконаних завдань, оскільки відповіді кожного учня автоматично фіксуються.

Зазначимо, що використання ЕНП у навчальному процесі має низку переваг у порівнянні 3 традиційним друкованим підручником:

- швидкий потік навчальної інформації;

- можливість використання мультимедійних засобів;

- моделювання процесів та явищ, що вивчаються, можливість проведення «комп’ютерних дослідів», які неможливо провести у класі;

- наявність системи проміжного контролю, самоперевірки знань.

ЕНП буде використовуватися як сучасний засіб навчання, якщо відповідатиме таким вимогам:

- науковість, доступність, проблемність, самостійність, системність [10]; 
- модульність, наявність чітко визначеної навчальної мети, орієнтування на самонавчання, послідовність, інтерактивність, наявність елементів супроводу [2];

- зміст навчального матеріалу відповідатиме сучасним вимогам навчального процесу та сприятиме розвитку особистості [11].

Отже, використання електронних навчальних посібників дозволяє розв'язувати сучасні освітні завдання, а також забезпечує індивідуалізацію навчального процесу в початковій ланці освіти.

Вдало дібрані комп'ютерні програми забезпечують розвиток творчих здібностей, стимулюють пізнавальну активність, емоційну сферу школярів. Під час використання ЕНП у навчальному процесі початкової школи, необхідно враховувати їх відповідність індивідуальним особливостям молодших школярів і специфіку конкретних навчальних предметів.

\section{Література}

1. Агеев В. Н. Электронние издания учебного назначения. Концепции, создание, использование: [учеб. пособ.] / В. Н. Агеев, Ю. Г. Древс. - М.: МГУП, 2003. - 236 с. 2. Бейлинсон В. Г. Характеристика, подготовка, конструирование учебных изданий / В. Г. Бейлинсон. - М.: Арсенал образования, 2006. 286 с. 3. Беспалько В. П. Теория учебника: Дидактический аспект / В. П. Беспалько. - М. : Педагогика, 2008. - 160 с. 4. Воронина Т. П. Образование в эпоху новых информационных технологий / Т. П. Воронина, В. П. Кашицин, О. П. Молчанова. - М. : Информатика, 1995. -220 с. 5. Зуев Д. Д. Школьный учебник / Д. Д. Зуев. - М. : Педагогика, 1999. - 240 с. 6. Краевский В. В. Дидактические основания определения содержания учебника / В. В. Краевский, И. Я. Лернер // Проблемы школьного учебника. - Вып. 8. - М. : Просвещение, 2003. - 305 с. 7. Крук Б. И. Электронный учебник как средство субъектно-объектного инфовзаимодействия в процессе обучения: проблемы инфовзаимодействия / Б. И. Крук, О. Б. Журавлева, И. В. Калачев. - Новосибирск. - Вып. 2. - 2000. -189 с. 8. Лернер И. Я. Методологические проблемы дидактической теории построения учебника / Каким быть учебнику: Дидактические принципы построения / И. Я. Лернер. - Ч. 1. - М. : Просвещение, 1999. - 197 с. 9. Носкова Т. Н. Аудиовизуальные технологии в образовании / Т. Н. Носкова. - СПб. : СПбГУ- КиТ, 2004.- 99 с. 10. Родин В. П. Создание электронного учебника: концепция и способ реализации: [учеб. издание] / В. П. Родин. - М. : Венец, 2008. - 31 с. 11. Тоискин В. С. Теоретические основы разработки электронных образовательных изданий (антропологический подход): [учеб. пособ.] / В. С. Тоискин, В. В. Красильников. - Ставрополь : СГПИ, 2010. - 108 с.

УДК 37.091.212.7:004.4

Надія Олефіренко

\section{ВИКОРИСТАННЯ ЕЛЕКТРОННИХ ДИДАКТИЧНИХ РЕСУРСІВ ДЛЯ ЗАКЛАДАННЯ ОСНОВ УСПІШНОСТІ МОЛОДШОГО ШКОЛЯРА В ПОДАЛЬШОМУ НАВЧАННІ}

Олефіренко Н. В. Використання електронних дидактичних ресурсів для закладання основ успішності молодшого школяра в подальшому навчанні.

У статті виокремлено низку функцій електронних дидактичних ресурсів, спрямованих на закладання основ успішності подальшого навчання молодшого школяра. Наведено характеристику інструментальної, дослідницької функцій, функції розвитку інтелектуальних умінь молодшого школяра, мобілізаційної функції та функції сприяння формуванню цілісного світогляду.

Ключові слова: молодший школяр, електронні дидактичні ресурси, функції.

Олефиренко Н. В. Использование электронных дидактических ресурсов для закладывания основ успешности младшего школьника в дальнейшем обучении.

В статье выделен ряд функций электронных дидактических ресурсов, направленных на закладывание основ успешности дальнейшего обучения младшего школьника. Приведена характеристика инструментальной, исследовательской функций, функции развития интеллектуальных умений младшего школьника, мобилизационной функции и функции содействия формированию целостного мировоззрения.

Ключевые слова: младший школьник, электронные дидактические ресурсы, функции.

Olefirenko N. V. Using of electronic teaching resources for success of primary school children in further education.

In the article is defined a number of electronic teaching resource's functions for further success training of young pupil. It is given a characteristic of the instrumental and research functions, function 